\title{
EFEKTIVITAS PENERAPAN HUKUM TERHADAP TINDAK PIDANA KESUSILAAN YANG DILAKUKAN ANAK DI BAWAH UMUR DI PENGADILAN NEGERI MAKASSAR
}

\author{
Siti Zainab Yanlua
}

Mahasiswa Pascasarjana Universitas Muslim Indonesia Makassar

\begin{abstract}
Siti Zainab Yanlua, 0059.02.42.2015, "The effectivity of the criminal morality application committed by minors in the court of Makassar District ". Under the guidance of said Sampara as chairman and Satrih Hasyim as a member.

The purpose of the research is: (1) to find out the effectivity of the application of law against children in conducting criminal acts in the court of Makassar District, (2) to analyze and understand the factors affecting the effectivity of the application of law to the criminal acts committed by children in the Makassar District Court.

The research method used by using primary data through the respondents consisting of judges and parties' litigation by through direct interviews to respondents as a sample, its from 2014 to 2016. Data analysis by using qualitative analysis.

The results of this study indicate that: (1) based on the circumstances of success in the application of law against children who commit criminal acts less effective in the Makassar District Court. (2) the analysis of factors affecting the effectivity of the application of law to morality cases conducted by children in the Makassar District Court. A. The legal material in the law no.11 of 2012 on the criminal justice system of children is less clearly affirmed his crime, $b$. structure or culture of community law that is not familiar with the child criminal justice system. And the existence of internal factors that support and inhibit the effectivity in the application of morality law cases conducted by children.

Recommendation to the judges especially the judge of the child, in the judgment of the decision of the child should be seen the factors affecting the child to commit moral crime, so that in deciding the children in the form of educating is not retaliation and the government needs to provide special prisoners of the child so that children who are faced with the law can be nurtured and guided to be better and separate from adult prisoners.
\end{abstract}

Keywords:

effectivity, application of law, criminal morality, minors 


\begin{abstract}
Abstrak
Siti Zainab Yanlua, 0059.02.42.2015, "Efektivitas Penerapan Tindak Pidana Kesusilaan Yang Dilakukan Anak di bawah Umur di Pengadilan Negeri Makassar", dibawah bimbingan oleh Said Sampara selaku ketua dan Satrih Hasyim selaku anggota.

Tujuan penelitian untuk: (1) untuk mengetahui efektivitas penerapan hukum terhadap anak dalam melakukan tindak pidana kesusilaan di Pengadilan negeri makassar; (2) untuk menganalisis dan memahami faktor-faktor yang mempengaruhi efektivitas penerapan hukum terhadap tindak pidana kesusilaan yang dilakukan anak di Pengadilan Negeri makassar.

Metode Penelitian yang digunakan dengan menggunakan data primer melalui para responden yang terdiri dari hakim, dan pihakpihak yang berperkara dengan melalui wawancara langsung kepada responden sebagai sampel, yakni dari tahun 2014 sampai dengan tahun 2016. Data dianalisis dengan menggunakan analisis kualitatif.

Hasil penelitian ini menunjukkan bahwa: (1) berdasarkan keadaan perkara keberhasilan dalam penerapan hukum terhadap anak yang melakukan tindak pidana kesusilaan kurang efektif di Pengadilan negeri makassar. (2) Analisis faktor-faktor yang mempengaruhi efektivitas penerapan hukum terhadap kasus kesusilaan yang dilakukan anak di Pengadilan Negeri Makassar. a. Materi Hukum dalam Undang-undang No. 11 tahun 2012 tentang Sistem Peradilan Pidana Anak kurang mengaskan dengan jelas tindak Pidananya, b. Struktur atau budaya hukum masyarakat yang belum mengenal luas tentang Sistem Peradilan Pidana Anak. Serta adanya faktor-faktor yang intern yang mendukung dan menghambat keberhasilan efektivitas dalam penerapan hukum kasus kesusilaan yang dilakukan anak.

Rekomendasi Kepada para hakim Khususnya hakim anak, dalam penjatuhan putusan terhadap anak perlu dilihat faktor yang mempengaruhi anak melakukan tindak pidana kesusilaan, sehingga dalam menjatuhkan putusan terhadap anak berupa mendidik bukan bersifat pembalasan dan pemerintah perlu menyediakan tahanan khusus anak sehingga anak yang berhadapan dengan hukum bisa dibina dan di bimbing menjadi lebih baik dan terpisah dari tahanan orang dewasa.
\end{abstract}

Kata Kunci:

Efektivitas, Penerapan Hukum, Kesusilaan, Anak di Bawah Umur

\title{
A. PENDAHULUAN
}

ndonesia adalah negara yang berdasarkan atas hukum, sehingga setiap kegiatan manusia atau masyarakat yang merupakan aktivitas hidupnya harus berdasarkan pada peraturan yang ada dan norma-norma yang berlaku dalam 
masyarakat. Negara merupakan sebuah entiti (kesatuan wilayah) dari unsur-unsur pembentukan Negara yang di dalamnya terdapat berbagai hubungan kepentingan dari sebuah komuniti (masyarakat setempat) yang berlangsung secara timbal balik dan terikat oleh Kesatuan Wilayah.

Perundang-undangan yang lain yang telah dibuat pemerintah Indonesia untuk mendukung jaminnya hak-hak anak antara lain Undang-undang Nomor 4 Tahun 1979 tentang kesejahteraan anak; undang-undang Nomor 39 Tahun 1999 Tentang hak Aasasi manusia Undang-undang Nomor 3 Tahun 1997 tentang Pengadilan Anak, Undang-undang Nomor 23 Tahun 2002 tentang Perlindungan Anak dan Undang-Undang Nomor 11 tahun 2012 Tentang Sistem Peradilan Pidana Anak dan berbagai peraturan lainnya yang mengatur mengenai anak. Dengan dibuatnya berbagai peraturan tersebut terlihat, Negara pada dasarnya sangat memperhatikan dan melindungi hak-hak anak. Namun sayangnya ketika masuk kedalam ranah praktik yakni dalam penegakan hukumnya (law enforcement) sering mengalami permasalahan yang cukup pelik (Harkristuti, 2002:4).

Kasus pembunuhan yang menimpa Syifa (4) pada 17 Juli 2007 lalu. Ketika itu syifa ditemukan tewas di dalam sumur rumahnya. Syifa sendiri adalah adik sepupu Sudirman Yusuf dan Ibrahim Tutu. Sedangkan Hamska bin Nurdin dalah tetangga Syifa. Dalam mengusut kematian Syifa, awalnya Ibrahaim Tutu, Hamka bin Nurdin, dan Sudirman Yusuf hanya dijadikan saksi untuk seseorang yang bernama Ambo Tuwo. Belakangan Kepolisian Resor Makassar Timur justru membebaskan Ambo Tuwo, dan menjadikan Ibrahim, Hamka, Sudirman sebagai tersangka kasus itu, kata Najamuddin, kuasa hukum hamka. Ketiga terdakwa bukan pelaku pembunuhan Syifa. Sudah dari awal ketiganya sudah berulang kali menyatakan tidak membunuh Syifa akan tetapi proses hukum terus berjalan. Pada tahun 2007 Sudirman dan Hamka masih berstatus anak-anak diadili di Pengadilan Negeri makassar, dan akhirnya dihukum masing-masing enam tahun dan harus mendekam di Rumah tahanan makassar. Sedangkan Ibrahim yang sudah dewasa diadili Pengadilan Negeri makassar, dan dijatuhi hukuman 13 tahun penjara. Mahkamah Agung menerbitkan putusan Kasasi bernomor 887 K/Pid.Sus/2008 tertanggal 31 juli 2008. Dalam putusan itu disebutkan. Majelis hakim kasasi menyatakan ketiga terdakwa tidak bermasalah dan memerintahkan agar ketiganya dibebaskan

Putusan hakim akan mempengaruhi kehidupan anak sebagai pelaku tindak pidana. Oleh sebab itu hakim harus yakin bahwa putusan yang akan diambil dapat menjadi satu dasar kuat untuk mengembalikan dan mengantar anak menuju masa deapan yang lebih baik dan untuk mengembangkan dirinya sebagai warga yang harus bertanggungjawab bagi keluaraga, bangsa dan negara. Hal ini harus diperhatikan oleh hakim sebagai aparat penegak hukum dalam menengani kasus tindak pidana yang dilakukan oleh anak.

Padahal, apabila berdasarkan ketentuan di dalam Pasal 26 ayat (1) UU Pengadilan anak seharusnya dakwaan terhadap anak pelaku tindak pidana adalah 
maksimal setengah dari dakwaan orang dewasa, dan kalaupun anak melakukan tindak pidana yang diancam dengan pidana mati atau pidana penjara seumur hidup, maka pidana penjara yang dapat dijatuhkan kepada anak tersebut adalah paling lama 10 (sepuluh) tahun Pasal 26 ayat (2) UU No.3 Tahun 1997. Selain itu konsep pemidanaan pada dasarnya lebih berorientasi kepada individu pelaku atau biasa disebut dengan pertanggungjawaban individual/personal (individual responsibility) dimana pelaku dipandang sebagai individu yang mampu bertanggung jawab penuh atas perbuatan yang dilakukannya. Sehingga konsep pemidanaan lebih tepat untuk diterapkan kepada orang dewasa, karena anak adalah individu yang belum dapat menyadari secara penuh atas tindakan atau perbuatan yang dilakukannya, hal ini disebabkan karena anak merupakan individu yang belum matang dalam emosional dan berpikir.

\section{B. METODE PENELITIAN}

Obyek dari penelitian ini adalah Penerapan Hukum Tindak Pidakana Kesusilaan yang dilakukan Anak di Pengadilan Negeri Makassar dilakukan dengan tehnik wawancara dan menelaah teori-teori yang ada. Kemudian tehnik analisis bahan hukum yang digunakan pada penelitian ini adalah analisis data kualitatif. dalam uraian secara logis dan sistematis untuk menjawab rumusan masalah yang ada.

\section{HASIL PENELITIAN DAN PEMBAHASAN}

Efektivitas Penerapan Hukum Terhadap Anak dalam Melakukan Tindak Pidana Kesusilaan.

Anak sebagai pelaku tindak pidana sering dijumpai dalam kehidupan seharihari. Perilaku anak pelaku tindak pidana dikategori sebagai anak nakal atau melakukan pelanggaran hukum. Anak dalam kondisi demikian disebut dengan anak yang berkonflik dengan hukum

Dalam pembangunan hukum pidana positif indonesia. Memang telah diakui keberadaan sanksi tindak pidana. Penagnacaman sanksi tindakan dalam UU No.11 Tahun 2012 menunjukkan bahwa ada sarana lain selain sanksi pidana bersifat reaktif terhadap suatu perbuatan, sedangkan sanksi tindakan lebih bersifat antisipatif terhadap pelaku perbuatan.

Kebijakan dalam menerapkan hukum terhadap anak tidak dapat dilepaskan dari proses kebijakan penegakan hukum pidana anak dalam proses peradilan pidana anak. Oleh karena itu kebijakan penjatuhan sanksi hukum oleh hakim harus memberikan perlindungan hukum terutama pertimbangan-pertimbangan terhadap sanksi yang dianggap tepat dan rasional untuk dijatuhkan terhadap anak. Aparat penegak hukum khususnya para Hakim sebagai pihak yang diberi kewenangan baik dalam undang-undang No. 8 Tahun 1991 dan Undang-undang No. 11 Tahun 2012 di dalam penjatuhan pidana terhadap anak. Tuntutan bagi seorang hakim sebagaimana 
yang dalam undang-undang No.11 tahun 2012 yaitu hakim memiliki pengalaman di bidang anak-anak, memiliki minat, perhatian, dedikasi dan memahami masalah anak. Seorang hakim memiliki kewajiban dan kemampuan untuk memahami proses perkembangan kejiwaan anak-anak secara totalitas terhadap perilaku yang dikembangkannya dalam struktur kemasyarakatan.

Dalam proses peradilan anak yang terjadi akhir-akhir ini secara nyata dapat dilihat bahwa putusan-putusan pengadulan terhadap anak nakal yang melakukan tindak pidana lebih didominasi oleh putusan berupa pidana penjara sebagai bentuk pidana perampasan kemerdekaan pidana adalah pidana yang paling dihindarkan mengingat dampak negatif dan stigmatisasi. Oleh karena itu upaya optimalisasi putusan yang bukan penjara (sanksi Tindakan) dalam memberikan sanksi terhadap anak nakal, yakni dengan melakukan pembaharuan hukum pidana dengan mereformulasikan pengaturan sanksi yang tertuang dalam UU No.11 Tahun 2012 tentang sistem peradilan anak landasan nilai keadilan substantif dan nilai pembentuk undang-undang dapat melakukan pembenaran sistem pengancaman sanksi tindakan yang lebih bervariatif yang tidak hanya diperuntukan pada anak yang berusia 8-12 tahun saja tetapi kepada semua golongan anak.

Berdasarkan jumlah kasus kesusilaan yang dilakukan anak yang diperoleh di Pengadilan Negeri Makassar dari tahun 2014 hingga tahun 2016 terdapat 13 kasus yaitu 12 kasus dengan putusan penjara sedangan 1 kasus berupa tindakan dengan dikembalikannya kepada orang tua. Dengan berdasarkan jumlah umur anak dalam kasus kesusilaan dari tahun 2014 hingga tahun 2016 anak yang melakukan tindak pidana kesusilaan diumur 15 tahun terdapat 5 orang anak yang melakukan tindak pidana kesusilaan, umur 16 tahun terdapat 4 orang anak melakukan tindak pidana kesusilaan dan diumur 17 tahun terdapat 4 orang anak melakukan tindak pidana kesusilaan.

Salah satu upaya penanggulangan pencegahan dan penanggulangan kenakalan anak dalam kasus kesusilaan ini melalui penyelanggaraan sistem peradilan anak (Juvenile justice). Tujuan penyelenggara sistem peradilan anak tidak semata-mata bertujuan menjatuhkan sanksi pidana bagi anak yang telah melakukan tindak pidana kesusilaan. Tapi telah difokuskan pada dasar pemikiran bahwa penjatuhan sanksi tersebut sebagai sarana pendukung kesejahteraan anak sebagai pelaku tindak pidana kesusilaan.

Undang-undang No.11 Tahun 2012 tentang Sistem Peradilan anak yaitu pidana dan tindakan. Hal ini dapat kita lihat dalam Undang-undang No.11 Tahun 2012 Pasal 69, dinyatakan bahwa "Anak hanya dapat dijatuhi pidana atau dikenai tindakan berdasarkan ketentuan dalam Undang-undang ini".

Dalam pembangunan hukum pidana positif Indonesia memang telah diakui keberadaan sanksi tindakan selain sanksi pidana walaupun dalam KUHP menganut single track system yang hanya mengatur tentang satu jenis yaitu sanksi pidana (Pasal 10 KUHP). Kesusilaan sanksi pidana dalam UU No.11 Tahun 2012 menunjukkan 
bahwa ada sarana lain selain pidana sebagai penanggulangan sarana dalam kejahatan.

Sanksi Pidana yang dijatuhi pada anak yang melakukan kesusilaan dipertegas dalam Undang-undang No.11 Tahun 2012 Pasal 71 ayat (1), ayat (2) ayat (3) sedangkan sanksi tindakan dipertegas dalam Undang-undang No.11 tahun 2012 Pasal 82 ayat (1).

Putusan hakim akan sangat berpengaruh terhadap kehidupan anak selanjutnya. Oleh sebab itu hakim harus yakin benar bahwa putusan yang diambil akan dapat menjadi salah satu dasar yang kuat untuk mengembalikan dan mengantar anak menuju masa depan yang baik untuk mengembangkan dirinya sebagai warga yang bertanggung jawab bagi kehidupan bangsa dan negara.

Menurut penulis karena kekurang mampuannya anak untuk mempertanggungjawabkan perbuatannya maka penjatuhan sanksi bagi anak hendaknya bersifat orientasi kedepan. Artinya, pidana tidak dilihat sebagai pembalasan kepada anaktetapi dilihat sebagai sarana memperbaiki tingkah laku anak karena perbuatan antisosial yang dilakukan diluar kekuasaan anak itu sendiri. Kalaupun pemberian sanksi perlu dilakukan akan lebih baik sanksi tersebut bukanlah sanksi pidana namun sanksi tindakan.

Di ungkapkan salah satu hakim anak Pengadilan Negeri Makassar Wudiarso (wawancara, tanggal 14 Agustus 2017) bahwa secara umum dalam menjatuhkan pidana seorang hakim harus memperhatikan atau mempertimbangkan beberapa hal berikut:

1. Kesalahan pelaku

2. Motif dan tujuan dilakukan tindak pidana

3. Cara melakukan tindak pidana

4. Sikap batin pelaku

5. Riwayat hidup dan keadaan sosial ekonomi

6. Sikap dan tindakan pelaku sesudah melakukan tindak pidana

7. Pengaruh pidana terhadap masa depan pelaku

8. Pandangan masyarakat terhadap tindak pidana yang dilakukan

9. Pengaruh tindak pidana terhadap korban ataupun keluarga korban

10. Tindak pidana dilakukan dengan berencana.

1. Faktor-faktor yang Mempengaruhi Efektivitas Penerapan Hukum terhadap Anak melakukan Tindak Pidana Kesusilaan.

Adapun faktor-faktor yang mempengaruhi efektivitas penerapan hukum dalam tindak pidana kesusilaan yang dilakukan anak sebagai berikut:

$>$ Faktor Substansi Hukum

Perlindungan terhadap anak pada suatu masyarakat bangsa, merupakan tolak ukur peradaban bangsa tersebut, karenanya wajib diusahakan sesuai dengan 
kemampuan nusa dan dikalangan anak bahkan lebih dari itu penapat anak yang melakukan perbuatan tindak pidana tanpa mengenal status sosial dan ekonomi.

Anak yang melakukan perbuatan penyimpangan hukum Pasal 1 butir 2 UU No.11 Tahun 2012 tentang Sisten Peradilan Pidana Anak menyebutkan sebagai anak nakal. Proses sistem yang disediakan oleh pemerintah dibedakan dengan apa yang diberlakukan terhadap orang dewasa yang melakukan kejahatan. Dasar pemberlakuan demikian seperti yang dirumuskan dalam konsideran UU No.11 tahun 2012 tentang Sistem Peradilan Pidana Anak, bahwa dalam menghadapi dan menanggulangi berbagai perbuatan dan tingkah laku anak, perlu dipertimbangkan kedudukan anak dengan segala ciri dan sifatnya yang khas, walaupun anak telah dapat menentukan sendiri langkah perbuatannya berdasarkan pikiran, perasaan, dan kehendaknya, tapi keadaan sekitarnya dapat mempengaruhi perilakunya. Disinilah peran peradilan pidana anak, bahwa terhadap anak yang melakukan tindak pidana diharapkan diproses dengan mengedepankan pemahaman yang mendasar bahwa anak adalah tetap anak yang meliki ciri dan sifat khusus.

Anak yang belum berumur 12 (dua belas) tahun yang melakukan tindak pidana dalam UU No.11 tahun 2012, yang diancam dengan pidana melalui orangtua, wali, atau orang tua asuhnya agar anak tersebut tidak mengulangi perbuatan yang mengakibatkan dijatuhi sanksi. Sedangkan yang dimaksud dengan syarat tambahan misalnya kewajiban untuk melapor secara periodek kepada pembimbing masyarakat.

Sanksi pidana berorientasi pada pengenaan sanksi terhadap pelaku suatu perbuatan, sementara sanksi tindakan berorientasi pada perlindungan masyarakat. Sanksi tindakan tujuannya lebih bersifat mendidik dan sanksi yang tidak membalas. Sanksi tindakan semata-mata ditujukan pada prefensi khusus, yakni melindungi masyarakat dari ancaaman yang dapat merugikan kepentingan masyarakat. Dalam penanganan UU No.11 Tahun 2012 menunjukkan bahwa ada sarana lain selain sanksi pidana yang bersifat kreatif terhadap suatu perbuatan yang dilakukan anak, sedangkan sanksi tindakan lebih bersifat antisipasi terhadap pelaku perbuatan.

\section{$>$ Faktor Struktur Hukum}

Aparat hukum adalah orang atau pihak yang bertugas menerapkan hukum. Pengertian ini mencakup lingkup yang sangat luas, yaitu meliputi petugas pada tingkat atas, menengah dan bawah, juga meliputi tugas pelaporan,penyidikan, penuntutan dan peradilan. Dalam melaksanakan tugas-tugas penegakan hukum, petugas memiliki sesuatu pedoman yang memuat penagturan hukum, petugas memiliki sesuatu pedoman yang memuat penagturan di setiap unit kerja. Diasumsikan apabila aparat penegak hukum bekerja sesuai dengan tugasnya kemungkinan besar hukum akan efektif, demikian pulas sebaliknya. Contoh apabila penerapan hukum memiliki keseriusan menerapkan setiap pelaku tindak pidana kesusilaan yang dilakukan oleh anak akan lebih mudah dicegah namun apabila hukum materilnya maupun hukum acaranya. Upaya penerapan hukun secara 
sistematis harus memperhatikan 3 aspek, sehingga proses penerapan hukum dan keadilan dapat diwujudkan secara nyata.

Penelitian di Pengadilan Negeri Makassar menunjukkan secara umum aparat penegak hukum belum menunjukan keseriusan dalam menangani kasus kesusilaan yang dilakukan oleh anak. Peristiwa kesusilaan yang dilaporkan korban tidak cukup tragis di mata aparat sehingga seringkali tidak mendapatkan perhatian semestinya. Hal ini dapat dilihat dari lambatnya proses persidangan penanganan kasus kesusilaan yang dilakukan oleh anak. Kasus kesusilaan yang dilakukan oleh anak masih sangat butuh perhatian dari segi penerapan hukumnya.

\section{$>$ Faktor Sarana dan Fasilitasi}

Tindak pidana kesusilaan yang dilakukan oleh anak. Bukan hnya sekedar dilakukan perorangan tapi dilakukan juga secara berkelompok dan memaksa. Dalam mencegah tindak pidana yang dilakukan anak memerlukan sarana dan fasilitasi dengan melakukan penyuluhan serta berbagai mass media sudah bisa kita apa hukuman yang dikenakan kepada anak yang berhadapan dengan hukum.

Perlu penyediaan tahanan khusus bagi anak sehingga anak yang berhadapan dengan hukum tidak dimasukkan sama dengan tahanan orang dewasa. Dikarnakan dampak psikologis anak berbeda dengan dengan orang dewasa dan anak juga tidak merasa terkucilkan. Dan anak dapat merasa aman dan menjadi lebih baik.

Dalam pantai rehabilitasi anak penyediaan cukup memadai penyediaan cukup luas sarana ibadah dan praktek harus memadai dan anak dalam pantai penyediaan menyadari dengan kesalahan yang merekalakukan sehingga mereka beranggapan bahwa pembinaan yang meraka perbuat ini adalah merupakan suatu proses perbaikan terhadap diri mereka menuju pribadi yang lebih baik.

\section{$>$ Faktor Masyarakat}

Faktor masyarakat yang dimaksud disini adalah kesadaran masyarakat itu sendiri. Kesadaran hukum umumnya dipahami sebagai kerelaan warga negara untuk pada hukum dalam arti mematuhi larangan dan menjalankan perintah yang tercantum dalam aturan hukum dan kesadaran atas nilai-nilai yang terdapat di dalam diri manusia, tentang hukum yang ada atau tentang hukum yang diharapkan ada. Dicatat bahwa selama bertahun-tahun, upaya membangun kesadaran hukum lewat penyuluhan-penyuluhan telah direduksikan oleh pemerintah menjadi sematamata akan penyadaran akan kewajiban yang ditimbulkan oleh hukum.

Faktor lingkungan keluarga sebagai kelompok terkecil dalam masyarakat memegang peran yang sangat penting dalam proses pertumbuhan seseorang dan anak-anak menjadi sampai dewasa dan mandiri. Keluarga juga merupakan suatu wadah yang paling awal dan fundamental untuk membentuk suatu kepribadian seseorang serta tempat menjalin kasih sayang diantara anggota keluarganya 
Masyarakat merupakan poin penting dari upaya penanggulangan dan pemberatasan tindak pidana narkotika. Hukum mengikat bukan karena negara menghendakinya, melainkan karena merupakan perumusan dari kesadaran hukum masyarakat.

Dapat dikatakan budaya hukum akan mempengaruhi penolakan dan penerimaan masyarakat terhadap suatu peraturan hukum. Hal ini penting diperhatikan karena suatu peraturan hukum tanpa dukungan dari masyarakat, dapat berakibat tidak berwibawanya peraturan hukum tersebut. Dukungan ini hanya dapat diperoleh bila apa yang ditetapkan sebagai suatu peraturan oleh pihak yang berkompeten, selaras dengan keyakinan hukum masyarakat.

Kondisi masyarakat dimana peraturan hukum beralaku atau diterapkan mempunyai pengaruh yang kuat terhadap pelaksanaan pelayanan kasus kekusilaan yyang dilakukan anak disebabkan peran masyarakat sangat dominan sebagai obyek dari proses penerapan hukum terhadap kasus kesusilaan yang dilakukan anak akan sangat tergantung kepada ketaatan masyarakat terhadap undang-undang yang berlaku.

Kesadaran masyarakat akan hak-hak dikatakan penting sebab menjadikan warga bisa terhindar dari perlakuan diskrimanstif dari orang lain, termaksud pemerintah selain itu, mereka dapat menempuh langkah yang tepat apabila dalam kenyataan benar-benar mengalami pelanggaran hak. Dalam hal ini melanggar hakhak anak yang berhadapan dengan hukum. Kesadaran yang diharapkan oleh undang-undang setidaknya meliputi saksi keragaman ini menunjuk pada aspekaspek kualitas maupun kuantitas.

Perbuatan-perbuatan yang menyimpang tersebut, hukum harus tetap ditegakkan. Hukum berfungsi sebagai pengendalian sosial (social control), memaksa warga masyarakat untuk mematuhi perundang-undangan yang berlaku. Hukum yang tidak dikenal dan tidak sesuai dengan konteks sosialnya serta tidak ada komunikasi yang efektif tentang tuntutan dan pembaharuannya bagi warga negara tidak akan bekerja secara efektif. Dengan demikian komunikasi efektif dengan meningkatkan pemahaman masyarakat akan ketentuan hukum di bidang Kenakalan Anak sangat diperlukan dalam menanggulangi tindak pidana kesusilaan yang dilakukan anak.

\section{$>$ Faktor Budaya Hukum}

Kebudayaan sebagai suatu sistem hukum pada dasarnya mencakup nilai-nilai mendasari hukum yang berlaku. Nilai-nilai ini meruapakan konsepsi abstrak mengenai apa yang dianggap baik sehingga diikuti dan apa yag dianggap buruk dihindari. Nilai-nilai tersebut lazimnya merupakan pasangan nilai-nilai yang mencerminkan dua keadaan ekstrim yang harus diserasikan.

Kecenderungan anggota masyarakat yang suka berinteraksi dengan penegak hukum menunjukkan bahwa hukum telah dianggap sebagai kondisi yang dapat diperjual belikan. Banyak kalangan berpendapat bahwa hal ini bukan budaya, tetapi apabila suatu kejadian yang sama terulang sampai beberapa kali maka sukar untuk 
mengingkari kenyataan ini. Siapa sebagai sumber kejahatan tidaklah mudah, karena bagaimanapun dalam kegiatan ekonomi fenomena ini sangat dilandasi oleh penawaran dan pemerintaan sehingga tanpa keduannya faktor ini tidak mungkin terjadi demikian.

Penciptaan budaya hukum dikalangan penegakan hukum untuk menanamkan perilaku bukan semata-mata sebagai penegakan hukum, tetapi juga melekat peran sebagai pelindung dan pengayoman masyarakat yang terjadi hal penting dan mendasar guna mendukung pemberantasan Tindak Pidana Kesusilaan yang dilakukan Anak di Bawah Umur di Pengadilan negeri Makassar.

Kebudayaan pada dasarnya mencakup seperangkap nilai-nilali yang didalamnya terdapat konsep-konsep abstrak mengenai apa yang dianggap baik dan apa yang dianggap buruk. Semakin banyak persesuain antara perundang-undangan dengan kebudayaan masyarakat maka akan semakin baik pula upaya penerapan hukumnya dan demikin sebaliknya. Terjadinya tindak pidana kesusilaan khususnya yang dilakukan oleh anak di masyarakat Indonesia yaitu adanya ketimpangan sosial, diskriminasi masyarakat dimana budaya masyarakat kita yang bahwa derajat lakilaki lebih tinggi dari derajat perempuan sehingga hal ini menjadi salah satu pemicu adanya tindak pidana kesusilaan yang dilakukakan oleh anak. Kemudian terjadinya kekerasan dalam rumah tangga ini didorong oleh kondisi internal karakteristik pribadi anak atau psipatologi anak sehingga anak melakukan tindak pidana kesusilaan dan karakteristik pribadi korban atau di profokasi oleh pelaku.

Pemberian hukum terhadap anak hendaknya dijadikan sarana untuk merehabilitasi anak nakal tersebut dan melindunginya dari stigma buruk terhadapnya untuk itu negara harus tampil sebagi pelindung dan teman bagi anak bukannya sebagai pelaksanaan pembalasan masyarakat yang marah atas perbuatan jahat yang dilakukan oleh sianak. Penjatuhan pidana penjara yang tidak sesuai menimbulkan dampak negatif dan kerugian khususnya terhadap terpidana anak.

\section{KESIMPULAN DAN SARAN}

\section{Kesimpulan}

1. Penerapan hukum terhadap anak yang melakukan tindak pidana kesusilaan di kota Makassar kurang efektif. Hal ini terbukti dilihat dari kasus kesusilaan yang dilakukan anak putusan hakim ada berupa pembalasan atas perbuatan anak dan tempat penahanan khusus anak belum ada sehingga anak yang melakukan tindak pidana digabungkan dengan ruang tahanan orang dewasa

2. Faktor-faktor yang mempengaruhi efektivitas penerapan hukum tindak pidana kesusilaan yang dilakukan anak di Pengadilan Negeri Makassar: faktor Subtansi Hukum, faktor struktur hukum, faktor sarana dan fasilitasi, faktor masyarakat, faktor budaya hukum. 


\section{Saran}

1. Dalam penerapan hukum terhadap anak yang melakukan tindak pidana hakim dalam menjatuhkan hukuman harus melihat dari berbagai faktor dan hakim harus menjatuhkan suatu putusan berupa mendidik bukan berupa pembalasan sehingga anak tidak merasa terpuruk dan anak dapat menyadari kesalahan yang dilakukan sehingga tidak melakukan perbuatannya kembali, dan ruang tahanan harus berpisah dari orang dewasa karna anak merupakan penerus bangsa sehingga perlu bimbingan khusus terhadap anak.

2. Dalam faktor-faktor yang mempengaruhi efektifitas dalam penerapan hukum terhadap anak yang melakukan tindak pidana kesusilaan harus diperhatikan sehingga dalam penerapan hukum terhadap anak menjadi efektif dan kasus kesusilaan yang dilkukan anak semakin berkurang

\section{Daftar Pustaka}

\section{Buku:}

A. Fuad, Usfa, 2006, Pengantar Hukum Pidana, Penerbitan Universitas Muhammadiyah malang: Malang.

Abintoro Prakoso, 2013, Pembahuruan Sistem Peradilan anak, Cetakan Kesatu, Laksbang Grafika: Yogyakarta

Abdul Wahid dan Muhammad Irfan,2001, Perlindungan Terhadap Korban

Kekerasan Seksual, PT Refika Aditam: Bandung

Ahmad Ali, 2010, Menguak Teori Hukum dan Teori Peradilan, Kencana: Jakarta.

-2012,Penguak Teori Hukum (Legal Theory) dan Teori Peradilan (Judicial prudence)

Termaksud Interpretasi Undang-undang (Legisprudence), Kencana Prenada media Group: jakarta

Andi Hamzah,1994, Pelaksanaan Peradilan BerdasrakanTeori dan Praktek, Rineka Cipta: Jakarta

----------,1986. Sistem Pidana dan Pemidanaan Indonesia, Pradnya Paramita:Jakarta

Andi Sofyan dan Abdul Asis, 2014, Hukum Acara Pidana, Kencana: Jakarta

-1986, Sistem Pidana dan Pemidanaan Indonesia, Pradnya Paramita: Jakarta.

Aristo M.A. Pangribuan dkk, 2017, Pengantar Hukum Acara Pidana di Indonesia, PT Rajagrafindo Persada: Depok.

A.Zainal Abidin Farid,1995, Hukum Pidana I, Cetakan Pertama, Sinar grafika:Jakarta

Bachrul amin, 2013, Penerapan Sanksi Administrasi dalam Hukum Lingkungan, Laksbang Mediatama: Yogyakarta.

Bambang Sunggono,1997, Metodologi Penelitian Hukum, PT Raja Grafindo Persada: Jakarta 
Barda, Nawawi, Arief,1990, Perbandingan Hukum Pidana, RajaGrafindo: Jakarta.

Beccaria, cessare. On Crime and Punishment.Original Italia Title Dei Delittee Delle, English translation by Jane Grigson (1964). New York: Oxford University Press. 1996

Bimo, Walgito, 1982, kenakalanAnak (juvenile Delinquency), Yayasan Penerbitan Fakutas Psikologi UGM: Jakarta.

Darwan Prints,2003, Hukum Anak Indonesia, Citra Aditya: Bandung E. Utrecht, 1958, Hukum Pidana I, Universitas Jakarta: Jakarta. ,1987, Hukum Pidana II, Cetakan ketiga, Pustaka Tinta Mas:Surabaya

Gatot Suparmono, 2000, Hukum Acara Pengadilan Anak, djambatan: jakarta H.M. Hamdan, 2012, Alasan Penghapusan Pidana, Refika Aditama: Bandung. Hadi Supeno, 2010, Kriminalisasi Anak, Gramedia Pustaka Utama: jakarta Harkristuti Harkrisnowo,2002, Menelaah Konsep Sistem Peradilan Pidana Terpadu (Dalam Konteks Indonesia), Medan

Kartini Kartono, 1992, Kenakala nremaja,Rajawali: Jakarta Lamintang, P.A.F, 1984, Dasar-Dasar Hukum Pidana Indonesia, SinarBaru: Bandung.

Leden Marpaung, 1991, Unsur-unsur Perbuatan yang Dapat Dihukum, Cetakan Pertama, Sinar Grafika: Jakarta

Laden Marpaung, 2008, Asas-Teori-Praktik Hukum Pidana, Sinar Grafika:Jakarta Maulana Hasan Wadong,200, Pengantar Advokasi dan Hukum

Perlindungan Anak, PT. Gramedia Widasaran: Bandung Moeljatno, 1985,AzasAzas Hukum Pidana, Bina Aksara: Jakarta

1983, Asas-asas Hukum Pidana, Bina Aksara, jakarta Mohdar Yanlua, 2010, Ilmu Hukum, Karya Media, Yogyakarta

Mardjono Reksodiputro dkk, 1995, Pemasyarakatan Terpidana Anak dan Wanita. Dalam Masyarakat Yang Sedang Membangun, Sponsor: Masumoto FoundationJapan, Unversitas Indonesia: Jakarta

Muhammad Ainul Syamsul,2016,Penjatuhan Pidana dan Dua Prinsip dasar Hukum Pidana, Prenadamedia Group: jakarta

Muladi dan Barda, 1984, Teori-Teori dan Kebijakan Pidana, Alumni: Bandung

Muladi dkk, 1992, Teori-Teori dan kebijakan Pidana, Cetakan Kedua, Alumni: Bandung Muhammad Joni, dkk, 1999, Aspek Hukum Perlindungan Anak dalam Perspektif

Konvensi Hak Anak, Citra Aditya Bakti: Bandung Munadi Hidayat,2010, Pemidanaan anak di Bawah Umur, Alumni: Bandung

Nashriana, 2011, Perlindungan Hukum Pidana bagi anak di Indonesia, Raja Grafindo: Jakarta.

Paulus Hadisuprapto, 1997, Juvenile Delinquency. Pemahaman dan Penanggulangan, Citra Aditya Bakti: bandung

Ridwan H.R, 2011, Hukum Administrasi Negara, Raja Grafindo Persada: jakarta

R. Wiyono,2016, Sistem Peradilan PidanaAnak di Indonesia, Sinar Grafika: Jakarta Timur. 
Rodliyah dan Salim,2017, Hukum Pidana Khusus, PT GrafindoPersada: Depok Roeslan Saleh,1987,Stelsel Pidana Indonesia, Bina Aksara: Jakarta.

RomliAtmasasmita, 1983, Problem kenakalanAnak-AnakRemaja, Armico: Bandung. ,1982, Strategi Pembinaan Pelanggar Hukum Dalam Konteks Penegakan Hukum Di Indonesia, Armico: Jakarta

Said Sampara dan La Ode Husen, 2016, Metode Penelitian Hukum Edisi Revisi, KRETAKUPA Print: Makassar

Soedarto,1989, Hukum dan Hukum Pidana, Alumni: Bandung Soerjono Soekanto,2005, Faktor-Faktor Yang Mempengaruhi Penegakan Hukum, Raja Gravindo Persada: Jakarta.

Soerjono Soekanto dan Sri Mamudji,2001, Penelitian Hukum Normatif, Rajawali Pers: Jakarta

Sukanto, 1985, Nafsiologi Suatu Pendekatan Alternatif Atas Psikologi, Integritas Press: Jakarta

Suparni dan Niniek, 2007, Eksistensi Pidana Denda dalam Sistem pidana dan Pemidanaan, Sinar Grafika: Jakarta

Syamsuddin Pasamai,2013, Sejarah dan Sejarah Hukum, Arus Timur: Makassar

Teguh Prasetyo,2011, Hukum Pidana, Edisi revisi, rajawali Pers: Jakarta

Wagiato Soetodjo, 2006, Hukum Pidana Anak, Refika Aditam: Bandung

\section{Undang-undang}

Undang-Undang Dasar Negara Republik Indonesia 1945

Kitab Undang-Undang Hukum Pidana

Undang-Undang Nomor 39 Tahun1999 tentang HakAsasi Manusia

Undang-Undang Nomor 23 Tahun 2002 tentang Perlindungan Anak

Undang-Undang Nomor 11 Tahun 2012 tentang Sistem Peradilan Anak

\section{Media Online}

Hhttp://ww.Efektifitas Peradilan Anak Indonesia?id=22985\&jenis=Mimbar$\underline{\text { Advokat }}$ 